\title{
Counseling and education on adequacy of vitamin and mineral intake from fruit and vegetables to improve body immunity in senior high school students in Tanjung Morawa district
}

\author{
Siti Morin Sinaga ${ }^{1 *}$, Jansen Silalahi ${ }^{1}$, Henni Cintya ${ }^{1}$ \\ ${ }^{1}$ Faculty of Pharmacy, Universitas Sumatera Utara, Medan, Indonesia \\ *Email: sitimorin@usu.ac.id
}

\begin{abstract}
Fruits and vegetables are food ingredients that contain a lots of nutrients such as vitamins, minerals and fiber that are needed by the body. Indonesia is a country that is very rich in fruits and vegetables. However, in fact, fruits and vegetables are rarely consumed by people, especially teenagers. Lack of intake in consuming fruits and vegetables can cause the body to lack nutrients such as vitamins, minerals, fiber and an imbalance in the body's acid and alkaline, which can lead to various diseases. The purpose of this community service is to provide counseling and educate students and teachers about the adequate intake of vitamins and minerals from fruits and vegetables to increase immunity in Senior High School students in Tanjung Morawa District. This community service activity was carried out by means of a lecture method by disseminating the activity plan to the children of the Yayasan Pendidikan Pauly Mandiri students, then demonstrations by conducting counseling. Community service activities in general received a very good response and high enthusiasm from students, and several teachers who attended and the chairman of the Pauly Mandiri Education Foundation in Tanjung Morawa asked to be resumed. The results of community service, especially practicing how to create fruits and vegetables by making salads from various fruits and vegetables that can be applied by students and teachers in their daily lives. The enthusiasm of the participants hoped that this outreach activity could be resumed, namely how to make it easier for children to make it easier for children to remember the importance of consuming fruits and vegetables.
\end{abstract}

Keywords: Vitamins, minerals, vegetables, fruit, immunity.

\begin{abstract}
Abstrak
Buah dan sayur merupakan bahan makanan yang banyak mengandung nutrisi seperti vitamin, mineral serta serat yang sangat dibutuhkan oleh tubuh. Indonesia adalah negara yang sangat kaya dengan buah dan sayur. Tetapi kenyataannya, buah dan sayur masih jarang dikonsumsi oleh masyarakat khususnya para remaja. Kekurangan asupan dalam mengonsumsi buah dan sayur dapat menyebabkan tubuh kekurangan nutrisi seperti vitamin, mineral, serat dan tidak seimbangnya asam basa tubuh, sehingga dapat mengakibatkan timbulnya berbagai penyakit. Tujuan dari pengabdian kepada masyarakat ini adalah untuk memberikan penyuluhan serta mengedukasi siswa/siswi serta guru tentang kecukupan asupan vitamin dan mineral dari buah dan sayur untuk meningkatkan imunitas tubuh pada siswa/i SMA/SMK di Kecamatan Tanjung Morawa. Kegiatan Pengabdian Kepada Masyarakat ini dilakukan dengan metode ceramah dengan cara mensosialisasikan rencana kegiatan kepada anak-anak siswa/i Yayasan Pauly Mandiri, selanjutnya demonstrasi dengan melakukan penyuluhan. Kegiatan pengabdian kepada masyarakat secara umum mendapat sambutan yang sangatbaik dan antusias tinggi dari para siswa atau siswi, dan beberapa guru-guru yang hadir serta ketua Yayasan Pendidikan Pauly Mandiri di Kec. Tanjung Morawa meminta untuk dilanjutkan kembali. Hasil pengabdian kepada masyarakat, khususnya mempraktek cara mengkreasikan buah dan sayuran dengan membuat salad dari berbagai buah dan sayur yang dapat diaplikasi kan oleh siswa/i serta guru-guru dalam kesehariannya. Antusiasme dari peserta berharap supaya kegiatan penyuluhan ini bisa dilanjutkan kembali yaitu bagaimana tentang pedoman gizi sehat dan seimbang untuk anak-anak lebih mudah mengingat penting mengonsumsi buah dan sayur.
\end{abstract}

Kata Kunci: Vitamin, mineral, sayur, buah, imunitas. 


\section{Pendahuluan}

Gizi mikronutrien adalah masalah yang sedang dihadapi anak-anak serta para remaja di Indonesia, kurangnya asupan nutrisi seperti vitamin dan mineral yang terkandung dalam sayuran dan buah-buahan. Gizi burukseringkali tidak dianggap sebagai masalah yang serius. Padahal gizi burukmerupakan dampak dari keadaan kurang gizi yang terakumulasi dalam waktu yang cukup lama dan menjadi indikasi masalah kesehatan masyarakat. Ini berhubungan dengan meningkatnya risiko morbiditas dan mortalitas, mengurangi kapasitas fisik, terhambatnya perkembangan dan fungsi motorik serta mental. Gizi burukjuga sering mengakibatkan terhambatnya perkembangan mental, menurunnya prestasi sekolah, dan mengurangi kapasitas intelektual pada anak (Almatsier et al, 2011).

Anak-anak yang terhambat pertumbuhannya sebagai akibat asupan gizi yang kurang atau infeksi berulang berisiko lebih besar untuk mengalami penyakit bahkan kematian. Tingginya angka gizi burukpada anak sangat berkaitan erat dengan kondisi yang terjadi dalam waktu yang lama seperti kemiskinan, perilaku hidup bersih dan sehat yang kurang, kesehatan lingkungan yang kurang baik, pola asuh yang kurang baik dan rendahnya tingkat pendidikan (Sabaruddin, 2012). Akan tetapi, kejadian ini hendaknya tidak hanya dikaji dari faktor kemiskinan dan kurangnya pengetahuan masyarakat mengenai asupan gizi yang seimbang, tetapi bisa juga ditinjau dari kebiasaan, persepsi, sikap dan kepercayaan masyarakat terhadap kondisi gizi anak (WHO, 2015).

Berdasarkan penelitian yang dilakukan di berbagai wilayah Indonesia juga diperoleh hasil bahwa konsumsi buah dan sayur pada penduduk Indonesia relatif masih kurang, padahal Indonesia adalah Negara yang sangat kaya akan buah dan sayur. Berdasarkan hasil Riskesdas ditemukan bahwa remaja di Indonesia rata-rata sebesar 93,7\% memiliki perilaku konsumsi buah dan sayur yang kurang. Masyarakat Indonesia dianjurkan oleh Menkes terutama balita dan anak usia sekolah dianjurkan untuk mengkonsumsi sayuran dan buah-buahan 300-400 gram per orang per hari dan bagi remaja dan orang dewasa sebanyak 400-600 gram per orang per hari (Riskedas, 2013).

Kurangnya konsumsi buah dan sayur dapat mengakibatkan berbagai dampak yaitu menurunnya imunitas/kekebalan tubuh seperti mudah terkena flu, mudah mengalami stres atau depresi, tekanan darah tinggi, gangguan pencernaan seperti sembelit, gusi berdarah, sariawan, gangguan mata, kulit keriput, arthritis, osteoporosis, jerawat, kelebihan kolesterol darah dan kanker. Dampak lain disebutkan dalam laporan WHO ditemukan bahwa sebanyak $31 \%$ penyakit jantung dan $11 \%$ penyakit stroke di seluruh dunia disebabkan oleh kurangnya asupan buah dan sayur di dalam tubuh (Kemenkes, 2014). Rekomendasi kecukupan konsumsi buah dan sayur menurut WHO yaitu sebanyak 400 gram per hari atau sebanyak 3-5 porsi sehari. Selain itu, Piramida Petunjuk Makananmerekomendasikan untuk menyajikan buah sebanyak 2-4 kali dan sayuran sebanyak 3-5 kali dalam sehari.Tujuan pengabdian ini adalah untuk memberikan informasi, serta memberi masukan dan pemahaman melalui suatu diskusi yang intensif secara ilmiah tentangkecukupan asupan vitamin dan mineral dari buah dan sayur untuk meningkatkan imunitas tubuh pada siswa/i SMA/SMK di Kecamatan Tanjung Morawa. Sehingga hal ini sangat penting untuk dilakukan, karena informasi yang diperoleh dapat menjadi sumber wawasan kepada siswa/i di Kecamatan Tanjung Morawa terhadap kecukupan asupan gizi vitamin dan mineral dari buah dan sayur untuk menghindari berbagai penyakit yang berdampak bagi kesehatan (WHO, 2015). 


\section{METODE PELAKSANAAN}

\subsection{Waktu dan Lokasi}

Pengabdian kepada Masyarakat ini dilakukan Di SD-SMA Yayasan Pendidikan Pauly Mandiri Di Desa Butu Bedimbar Pasar VIII, Gg. Soponyono Kecamatan Tanjung Morawa. Pengabdian kepada masyarakat ini dilaksanakan pada tanggal 19 Agustus 2020.

\subsection{Metode}

Kegiatan Pengabdian Kepada Masyarakat ini dilaksanakan dengan beberapa tahapan, yaitu sosialisasi rencana kegiatan kepada pihak yayasan lokasi pengabdian dengan menetapkan waktu pelatihan, selanjutnya melakukan pembentukan kelompok sasaran kegiatan, dan pelaksanaan kegiatan. Kegiatan Pengabdian Kepada Masyarakat ini dilakukan dengan metode ceramah dengan cara mensosialisasikan rencana kegiatan kepada anak-anak siswa/i Yayasan Pauly Mandiri, selanjutnya demonstrasi dengan melakukan penyuluhan serta manmpilkan video animasi berkaitan dengan sosialisasi yang dilakukan.

\section{HASIL DAN PEMBAHASAN}

Kegiatan penyuluhan mengenai edukasi tentang kecukupan asupan vitamin dan mineral dari buah dan sayur untuk meningkatkan imunitas tubuh pada siswa/i SD-SMA di Kecamatan Tanjung Morawaberjalan dengan lancar dan mendapat sambutan yang sangat positif dari parapeserta.Para siswa/siswi dan beberapa beberapa guru serta ketua yayasan sebagai audient penyuluhan meminta upaya kegiatan penyuluhan dapat berkelanjutan dilakukan ditahun mendatang. Artinya kegiatan penyuluhan ini sangat digemari dan disukai dan sangat penting dilakukan karena dapat mengingatkan kembali para siswa dan siswi akan pentingnya mengonsumsi sayur dan buah untuk kesehatan anak.

Remaja adalah salah satu kelompok usia yang paling rentan jika kurang konsumsi buah dan sayur yaitu karena masa remaja merupakan periode yang penting pada pertumbuhan dan kematangan manusia. Periode ini merupakan saat yang tepat untuk membangun tubuh dan menanam kebiasaan pola makan yang sehat, karena jika sejak remaja pola makan seseorang sudah tidak sehat, maka hal tersebut akan berdampak pada kesehatan di masa yang akan datang.Anak-anak yang terhambat pertumbuhannya sebagai akibat asupan gizi yang kurang atau infeksi berulang berisiko lebih besar untuk mengalami penyakit bahkan kematian (WHO, 2015).

Berdasarkan hasil pengamatan setelah dilakukan penyuluhan gizi dan kesehatan, perilaku kesehatan para siswa dan siswi membaik, terbukti dengan banyaknya respon dan antusias anak-anak atau siswa/i yang ikut menyaksikan dalam mempraktekkan cara membuat salad buah dan sayur untuk menarik perhatian anak untuk menyukai buah dan sayur. Konsumsi sayuran dan buah perlu ditingkatkan, karena buah dan sayur memiliki kandungan antioksidan yang tinggi yang mampu melawan terjadinya radikal bebas (perusakan sel dan jaringan) di dalam tubuh. Supaya buah dan sayur dapat terkonsumsi dengan maksimal, lebih baik disajikan berupa jus, atau membuat salad dengan variasi buah-buahan dan sayuran yang berwarna. Sehingga terpenuhilah asupan vitamin dan mineral didalam tubuh. Selain pemenuhan makanan sehari-hari, kebutuhan air putih minimal 2,5 liter dalam satu hari harus dipenuhi. Berdasarkan penelitian yang dilakukan di berbagai wilayah Indonesia juga diperoleh hasil bahwa konsumsi buah dan sayur pada penduduk Indonesia relatif masih 
kurang, padahal Indonesia adalah Negara yang sangat kaya akan buah dan sayur (Kemenkes, 2014).

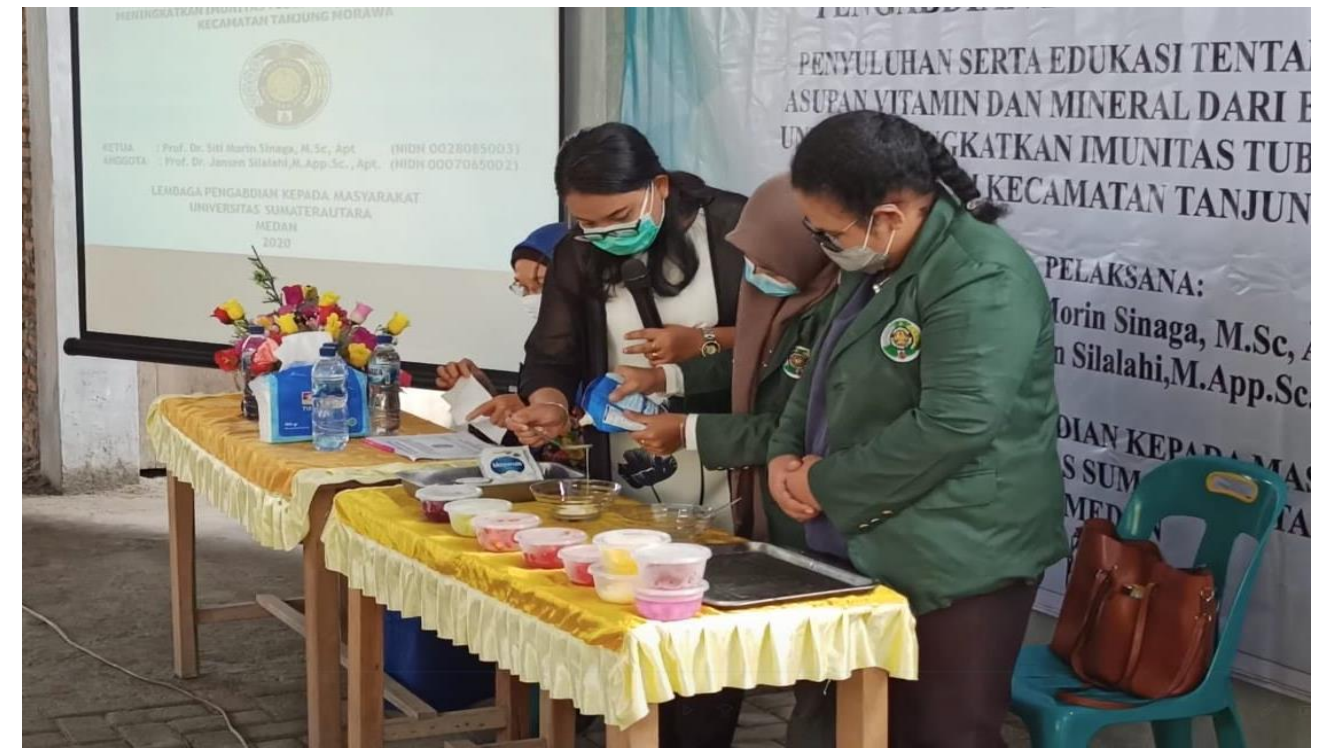

Gambar 1. Demonstrasi cara pembuatan salad buah dan sayur

Berdasarkan hasil Riskesdas ditemukan bahwa remaja di Indonesia rata-rata sebesar 93,7\% memiliki perilaku konsumsi buah dan sayur yang kurang. Masyarakat Indonesia dianjurkan oleh Menkes terutama balita dan anak usia sekolah dianjurkan untuk mengkonsumsi sayuran dan buah-buahan 300-400 gram per orang per hari dan bagi remaja dan orang dewasa sebanyak 400-600 gram per orang per hari (Riskedas, 2013).

\section{KESIMPULAN}

Kegiatan pengabdian kepada masyarakat secara umum mendapat sambutan yang sangat baik dan antusias tinggi dari para siswa atau siswi, dan beberapa guru-guru yang hadir serta ketua Yayasan Pendidikan Pauly Mandiri di Kecamatan Tanjung Morawa meminta untuk dilanjutkan. Hasil pengabdian kepada masyarakat, khususnya mempraktek cara mengkreasikan buah dan sayuran dengan membuat salad dari berbagai buah dan sayur yang dapat diaplikasi kan oleh siswa/i serta guru-guru dalam kesehariannya. Antusiasme dari peserta berharap supaya kegiatan penyuluhan ini bisa dilanjutkan kembali yaitu bagaimana tentang pedoman gizi sehat dan seimbang untuk anak-anak lebih mudah mengingat penting mengonsumsi buah dan sayur. 


\section{UCAPAN TERIMA KASIH}

Ucapan terima kasih yang setulus-tulusnya penulis sampaikan kepada Lembaga Pengabdian Pada Masyarakat (LPPM) Universitas Sumatera Utara yang telah mendanai kegiatan pengabdian ini. Terimakasih kepada Prof. Tulus, Vor.Dipl.Math., M.Si., Ph.D. selaku Ketua Lembaga Pengabdian kepada Masyarakat Universitas Sumatera Utara dan Prof. Dr. apt. Masfria, M.S selaku Dekan Fakultas Farmasi Universitas Sumatera Utara serta pihakpihak lain yang dengan tulus dan ikhlas telah membantu PKM ini baik secara langsung maupun tidak langsung.

\section{DAFTAR PUSTAKA}

Almatsier S, Soetardjo S, dan Soekarti M. (2011). Gizi Seimbang dalam Daur Kehidupan. PT. Gramedia Pustaka Utama. Jakarta. Hal. 330-333.

Kemenkes. (2017). Tingkatkan konsumsi sayur dan buah nusantara menuju masyarakat hidup sehat. Diakses tanggal 29 April 2020. Tersedia di: https://www.kemkes.go.id/article/view/17012500002/tingkatkan-konsumsi-sayur-danbuah-nusantara-menuju-masyarakat-hidup-sehat-.html

Kemenkes. (2014). Angka Kecukupan Gizi yang Dianjurkan Bagi Bangsa Indonesia. Direktorat Bina Gizi.Direktorat Jendral Bina Gizi dan Kesehatan Ibu dan Anak. KementerianKesehatan Republik Indonesia. Diakses tanggal 30 April 2020. Tersedia di:http://hukor.kemkes.go.id/uploads/produk_hukum/PMK\%20No.\%2041\%20ttg\%20P edoman\%20Gizi\%20Seimbang.pdf

Riset Kesehatan Dasar. (2013). Pedoman Pewawancara Petugas Pengumpul Data. Badan Litbangkes, Depkes RI. Diakses tanggal 30 April 2020. Tersedia di: https://www.kemkes.go.id/resources/download/general/Hasil\%20Riskesdas\%202013.pdf

Sabaruddin, E. N. (2012). Study on Positive Deviance of Stunting Problems among Under Five Children from Poor Family in Bogor City. Diterbitkan 12 April 2012. https://123dok.com/document/wq2wogeq-study-positive-deviance-stunting-problemschildren-family-bogor.html

World Health Organization (2015). Nutrition Landscape Information System (NLiS), Help Topic: Child Malnutrition. Cited 30 April 2020. Available on: https://www.who.int/nutrition/nlis/en/ 